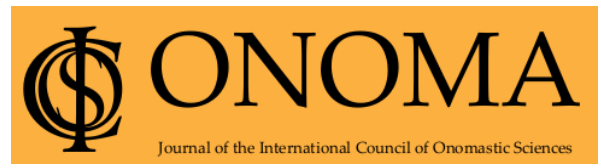

Onoma 56

Journal of the International Council of Onomastic Sciences

ISSN: 0078-463X; e-ISSN: 1783-1644

Journal homepage: https://onomajournal.org/

\title{
Katharina Leibring, Leila Mattfolk, Kristina Neumüller, Staffan Nyström, \& Elin Pihl (eds.), The economy in names. Values, branding and globalization: Proceedings of Names in the Economy 6 International Conference, Uppsala, 3-5 June 2019, Uppsala: Institutet för språk och folkminnen, 2021, 155 pp., ISBN: 978-91- 86959-73-9
}

\section{Sergey Goryaev*}

Department of Russian Language, General Linguistics and Speech Communication, Ural Federal University

To cite this article: Goryaev, Sergey. 2021. Katharina Leibring, Leila Mattfolk, Kristina Neumüller, Stafan Nyström, \& Elin Pihl (eds.), The economy in names. Values, branding and globalization: Proceedings of Names in the Economy 6 International Conference, Uppsala, 3-5 June 2019, Uppsala: Institutet för språk och folkminnen, 2021, 155 pp., ISBN: 978-91-86959-73-9. Onoma 56, 305-310. DOI: 10.34158/ONOMA.56/2021/17

To link to this article: https://doi.org/10.34158/ONOMA.56/2021/17

(C) Onoma and the author.

Article history

Received on 14 November 2021.

Final form accepted on 11 December 2021.

Published online on 13 December 2021. 


\section{Katharina Leibring, Leila Mattfolk, Kristina Neumüller, Staffan Nyström, \& Elin Pihl (eds.), The economy in names. Values, branding and globalization: Proceedings of Names in the Economy 6 International Conference, Uppsala, 3-5 June 2019, Uppsala: Institutet för språk och folkminnen, 2021, 155 pp., ISBN: 978-91-86959-73-9}

SERGEY GORYAEV

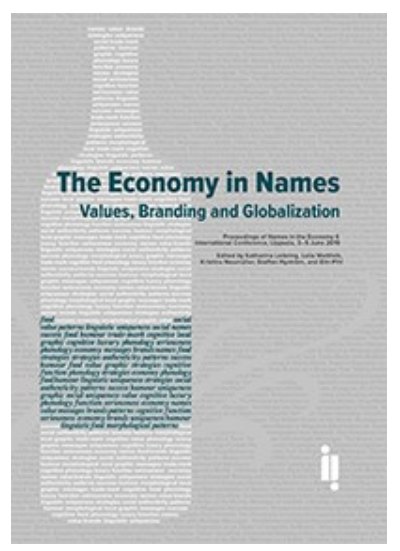

(https://www.isof.se/nite6)

The shoreless ocean of onomastics reflects all spheres of human society, all kinds of social relations, including, of course, economics. And naturally, the close connections between name and economy cannot but attract the attention of researchers, both linguists and specialists from related fields of science. In the past decades, a series of symposiums called Names in the Economy has been held: Antwerp (2006), Vienna (2007), Amsterdam (2009), Turku (2012), Verona (2015) and Uppsala (2019). The last conference led to the appearance of a collection of articles whose content will be considered below. It is safe to assume that this series of conferences, inspired at one time by Professors Ludger Kremer and Elke Ronneberger-Sibold, has significantly enriched the understanding of this field of onomastics. We believe, without absolutizing, that largely under the influence of these conferences, Paula Sjöblom (a permanent participant of NITE conferences and organiser of one of these events) described the concept of commercial name and introduced it into onomastic textbooks (Sjöblom 2016). This is important, because over the last two decades many articles and books which focused on the topic of commercial names began with the authors proving in detail why trademarks, brands, company names, etc. should be considered proper names. Now there is no doubt that commercial names are a category of onomastics in the strictest sense of the term.

The articles in the volume are arranged in alphabetical order; therefore, the collection opens with the article "Drug Names as a Business Tool" by Ilia Baranov (independent researcher, Moscow). It is interesting to note that in his research into commercial names, developing the topic of brand lifespan, Ilya 
Baranov operates with the statistical method of survival analysis, designed primarily for medical purposes. Thus, in the current article related to trade names of antiallergic drugs in Russia, he returns this method to medical topics. Based on statistical data, the researcher clearly shows the correlation between drug lifespan in the market and linguistic features of drug brands, such as semantic, graphic, grammatical and phonetic characteristics.

In the following article, entitled "Selling Political Messages", Angelica Bergien (Otto von Guericke University of Magdeburg) observed a deep relationship between brands and politics. In a broader sense she raises a question about the expression of a company's attitude to political issues in brands. On the one hand, to incorporate political messages in brand names may imply risks for businesses, since this may alienate dissenting customers. On the other hand, in the context of the present-day interaction between producers and consumers, conditioned by social media, the rejection of a clear political position also leads to the loss of the struggle for the consumer. In practical terms, Angelica Bergien analyses brands of British companies in which the topic of Brexit is reflected.

In the article with the intriguing title "The Hidden Power of the Words", Paola Cotticelli Kurras (University of Verona) discusses Italian wine brands. Starting with an outline of the Italian wine market, as well as its tradition and reform in accordance with the rules of the European Union, she focuses on the function of language in wine brand naming and labelling. To describe the correlation between onomastic creativity and marketing strategies through a linguistic-semantic analysis of brand names, the author shows linguistic and rhetorical strategies of wine naming, while noting that the consumer should be included in the cultural tradition. The article further reveals the semiotics of the wine label and provides a number of illustrations.

Wine is also the topic of the following article, "Message on a Bottle", by Alberto Ghia (University of Turin). The author focuses on a specific wine region of Italy and describes a corpus of wine names from the vineyards of the province of Asti, Piedmont, on four levels: linguistic (there are other languages mentioned in addition to Italian, even Japanese), morphosyntactic (for example, the peculiarities of the use of the article are discussed), grapho-phonetic (with special attention to the Piedmontese dialect), and semantic (there is a predominance of existing words or well-constructed sentences). It is interesting to note that Alberto Ghia is in line with the previous author not only as regards the subject, but also the theoretical approach. Thus, the two articles form a united thematic block.

In the article "The Persuasive Function of Company Names", Linnea Gustafsson (Halmstad University) uses for analysis the data she collected from four different business sectors - names of dental practices, real estate agencies, cleaning companies, and restaurants in the city of Uppsala. Such a wide range is needed to study similarities and differences in the realisation of the persuasive function of commercial names. The material is considered in relation to four aspects reflecting the existence of commercial name in language and society: 
personal names, locality, seriousness or humour, choice of language. The author points out significant similarities between dental practices and real estate agencies, on the one hand, and between cleaning companies and restaurants, on the other. Possible reasons for the occurrence of these similarities are discussed.

The title of the paper "Italian Sounding", by Sabine Heinemann (University of Graz), hints at the main subject of consideration, that is, Italian or pseudoItalian brand names patented in Germany and France. The article contains a detailed description of the theoretical basis whose main points are the conception of associative networks, elaborated in cognitive psychology, the idea of complex semiotic model and the concept of frame evoked by a single brand name. This approach allows one to state that "the semantic content of brand names sounding Italian is in some cases analysable" (Heinemann 2021: 67). It is interesting to note the author's caution in this statement, because despite the wealth of theoretical approaches, proper-name semantics is still disputable.

The following article, "Entrepreneurial, Naming and Scaling of Urban Places", was co-authored by Johan Järlehed, Maria Löfdahl (Institute for Language and Folklore, Gothenburg), Tommaso Milani, Helle Lykke Nielsen (University of Southern Denmark) and Tove Rosendal. Except the authors noted separately, the other researchers represent the University of Gothenburg. The authors offer a kind of case study and, based on the concept of urban entrepreneurialism, describe the advertising campaign, naming, signing and branding performed by the principal entrepreneur of Nya Hovås, a new neighbourhood in Gothenburg. To us, the authors' intention seemed dominated by the theory of branding rather than by a clear onomastic approach. Therefore, we especially highlight the onomastic issues considered by the authors: onomastic landscape, urban place naming, and the involvement of toponyms in commercial onomastics.

The reader of the article "Russian Ergonyms as an Object of Linguistic Reflexion", by Irina Kryukova (Volgograd State Socio-Pedagogical University), should bear in mind that in Russian linguistics the term ergonym has long been firmly entrenched with the meaning 'company name' or, in a broader sense, 'a name of any organization or association of people'. Irina Kryukova studies the linguistic reflexion of ergonym, namely the statements of Russian native speakers about them. Two separate sections are focused on name givers and recipients' reflexions. The cases when the expectations of naming subjects and addressees do not match are described separately in the section "Nominative failures".

In the article "Remarks on Nomination between Ergonymy and Toponymy", Antje Lobin (Johannes Gutenberg University Mainz) focuses on commercial names derived from toponyms - shop and restaurant names containing the name or part of the name of the city or village where they are located and demonstrating a high level of creativity. Data from several communes of Provence served as the materials for the research. Antje Lobin observes possible ways of place branding and shows a potential formal systematisation, in particular. The author contrasts regular word-formation 
patterns of French and blending techniques. Apparently, this study should be attributed to glocalisation research, although the author does not use this term.

The article "Trade Marks with Multiple Messages" revealed one of the most important aspects of the existence of commercial names, the legal aspect. Erika Lunell (Örebro University) describes trademark protection in the light of EU rules and norms. The focus of the paper is distinctiveness, the ability of distinguish certain goods or services from those with another origin. Although distinctiveness concerns not only words, but also other elements, such as shapes, colours and even scent, specific linguistic issues are addressed: e.g, the borderline between traditional trademarks and descriptive ones, especially unclear in compound marks; the connection of trade names with other proper names, particularly with owners' names; using advertising slogans as trademarks.

Katalin Reszegi (University of Debrecen) is known for her cognitive onomastic research. In the current article, "The Mental and Neural Representation of Names", she turns to the analysis of brand names. The article has a pronounced theoretical character, since one of the author's aims is to show how knowledge of the mental representation of names can be used for further development of the proper name theory. The issues of proper and common names, proper name meaning and classification, and features of brand names as a proper name category are highlighted in neurolinguistic and psycholinguistic terms. According to the practical aspect, however, the conclusion turns out to be that there is no direct formula for an ideal brand name.

The title of the article by Paula Sjöblom (University of Turku), "Women's Values in 1950s Finland Conveyed by Product Names in Magazine Advertisements", is sufficiently indicative of the main point of the paper. The author's central approach is initially declared as rhetorical but almost immediately expands to semiotics. The research is focused not only on product names, their semantics, language of origin, associations evoked, but also on the graphic features and visual position of names in advertisement. The author speaks sparingly even about the general design of magazine covers. As a result, the author persuasively forms a list of factors reflecting the value consciousness of the female journal audience. A practical conclusion is also interesting: "a critical observation of product names should be included in advertising literacy" (Sjöblom 2021: 140), and one can only agree with this.

The article concluding the volume also uses visual sources. Väinö Syrjälä (Södertörn University, Stockholm), in "Commercial Naming in the Linguistic Landscape of Historical Photographs from Helsinki", analyses historical data from 1867 to 1939 . The article includes a detailed review of the literature on commercial names in onomastic landscape, which, of course, will be useful to everyone investigating this topic, with two observations ensuing. On the one hand, the author considers the question of multilingualism, more precisely, the complex relationship between Swedish, Finnish, and Russian. On the other, the author focuses on the types and characteristics of commercial names captured in photographs. 
In conclusion, we would like to note that the reviewed volume is the next step in the history of the conferences "Names in the Economy" and in the development of the topic of commercial names. The present collection contains articles illustrating a traditional approach, describing, for example, the names of a certain market area, and researches reflecting new approaches, such as from the viewpoint of neurolinguistics. This demonstrates the inexhaustibility of the scientific subject. As Katharina Leibring and Stafan Nyström, the authors of the "Preface" of reviewed book, rightly note, "our knowledge of the multidisciplinary field of onomastics and economy has deepened during the last decades", but at the same time, "there still are many new avenues to explore" (Leibring \& Nyström 2021: 6).

\section{References}

Sjöblom, Paula. 2016. Commercial names. In Hough, Carole (ed.), with Izdebska, Daria, The Oxford handbook of names and naming, 453-464. Oxford: Oxford University Press. 